\title{
High Temperature Tensile and Abrasive Wear Characteristics of As-cast Ductile Irons
}

\author{
Ozgur CELIK, Hayrettin AHLATCI, Eyup Sabri KAYALI and Hüseyin ÇIMENOǦLU \\ Istanbul Technical University, Department of Metallurgy and Materials Engineering, 34469 Maslak-Istanbul, Turkey. \\ E-mail: hcimen@itu.edu.tr
}

(Received on December 11, 2002; accepted in final form on February 24, 2003)

\begin{abstract}
In this study, tensile and abrasive wear performances of two different quality as-cast ductile irons have been examined at various temperatures between 25 and $600^{\circ} \mathrm{C}$. Tensile tests were carried out with a strain rate of $3 \times 10^{-4} / \mathrm{s}$. Wear tests were performed under a compression stress of $5.7 \mathrm{~N} / \mathrm{mm}^{2}$, by rubbing samples on $125 \mu \mathrm{m} \mathrm{Al}_{2} \mathrm{O}_{3}$ abrasive grains. In the temperature range of $100-300^{\circ} \mathrm{C}$, where serrated flow is observed during tensile testing, tensile strength values of both ductile irons were invariable. Above $400^{\circ} \mathrm{C}$, further increase of temperature caused dramatic decrease in tensile strength. As a general trend, abrasive wear resistances of the both ductile irons increased with increasing tensile strength. Exceptionally, maximum resistance to abrasive wear is obtained from both ductile irons at $100^{\circ} \mathrm{C}$, probably due to dynamic strain aging.
\end{abstract}

KEY WORDS: abrasive wear; ductile iron; high temperature; strain aging; tensile characteristics.

\section{Introduction}

Ductile irons, which have been used in wear related engineering applications, such as motor blocks, pistons, crankshafts, gears and rolls for hot rolling, are of considerable current interest because they can offer excellent combination of strength and toughness. The wear performance of a ductile iron is significantly influenced from the microstructure. ${ }^{1-7)}$ In as-cast condition, pearlitic microstructure, consisting of very hard lamellar carbide in a soft ductile matrix of ferrite, exhibits superior wear resistance than ferritic microstructure. Further improvement of wear resistance can be achieved by applying austempering heat treatment, which results in bainitic microstructure. However, decomposition of bainite limits the use of austempered ductile irons at elevated temperatures, whilst the microstructure of as-cast ductile irons retains its stability up to $600^{\circ} \mathrm{C}$.

Previous investigations were concentrated on room temperature wear behaviours of as-cast and austempered ductile irons. Since there is no literature related with high temperature wear performance, examination of abrasive wear characteristics of as-cast ductile irons at elevated temperatures was aimed in the present study.

\section{Experimental Procedure}

The microstructures of the as-cast ductile irons utilised in the present study are shown in Fig. 1. In the microstructures, spheroidal graphites are uniformly distributed in the matrix, which consists of ferrite and pearlite. The features of the examined ductile irons including characteristics of microstructural components and bulk hardness are listed in
Table 1.

Mechanical properties of the examined ductile irons were determined by tensile tests carried out between room temperature and $600^{\circ} \mathrm{C}$. Round-type tensile specimens with $5 \mathrm{~mm}$ gauge diameter and $25 \mathrm{~mm}$ gauge length were utilised for tensile tests. Specimens were held at test temperatures for $15 \mathrm{~min}$ before tensile testing. Tensile tests were conducted on an Instron 1185 Universal testing machine, with a constant strain rate of $3 \times 10^{-4} / \mathrm{s}$.

Wear performances of the ductile irons were examined by using the metal-abrasive type wear tester schematically illustrated in Fig. 2. Abrasive wear tests were carried out at various temperatures up to $600^{\circ} \mathrm{C}$. Wear test specimens, having tip diameter of $3 \mathrm{~mm}$ and length of $30 \mathrm{~mm}$ were heated to test temperatures by means of an electrical resistance heater and held at test temperature for $30 \mathrm{~min}$ before the tests. Wear tests were performed by rubbing the specimens on 120 mesh $\mathrm{Al}_{2} \mathrm{O}_{3}$ abrasive grains bonded bands under a normal pressure of $5.7 \mathrm{~N} / \mathrm{mm}^{2}$ with a sliding speed of $0.24 \mathrm{~m} / \mathrm{s}$. During the wear tests, specimens moved perpendicular to the sliding direction so that they were always in contact with fresh abrasive grains. Total sliding distance of the specimens on abrasive bands was $11 \mathrm{~m}$. The results of wear tests were quantified as the weight loss of the specimens measured with $0.1 \mathrm{mg}$ sensitivity.

At least two tensile and wear tests were made at each test temperature and their results were averaged to evaluate the characteristics of the specimens. After the tests, tensile fracture and worn surfaces of the specimens were examined by JEOL JSM-6335F type scanning electron microscope (SEM). 


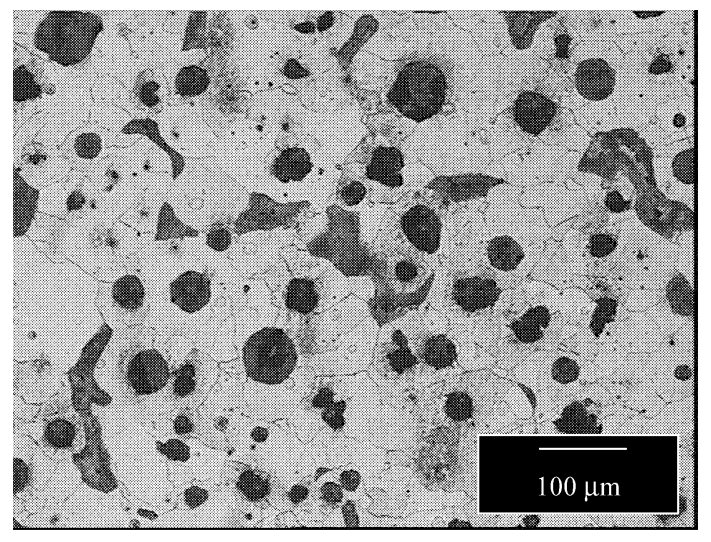

(a)

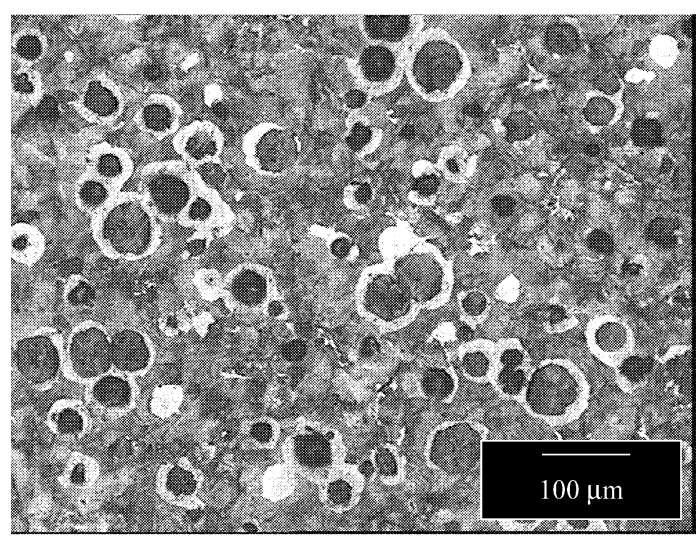

(b)

Fig. 1. Microstructures of the investigated ductile irons in ascast condition, (a) the material DI 1 and (b) the material DI 2.

Table 1. The characteristics of investigated ductile irons. ${ }^{8)}$

\begin{tabular}{|c|c|c|c|c|c|c|}
\hline \multirow{3}{*}{$\begin{array}{l}\text { Material } \\
\text { Code }\end{array}$} & \multicolumn{3}{|c|}{ Volume Fraction (\%) } & \multicolumn{2}{|c|}{ Graphite } & \multirow{3}{*}{$\begin{array}{c}\text { Hardness } \\
\left(\mathrm{HV}_{20}\right)\end{array}$} \\
\hline & \multicolumn{2}{|c|}{ Matrix } & \multirow[t]{2}{*}{ Graphite } & \multirow{2}{*}{$\begin{array}{l}\text { Size } \\
(\mu \mathrm{m})\end{array}$} & \multirow{2}{*}{$\begin{array}{c}\text { Nodularity } \\
(\%)\end{array}$} & \\
\hline & Ferrite & Pearlite & & & & \\
\hline DI 1 & 84 & 5 & 11 & 25 & 78 & 155 \\
\hline DI 2 & 15 & 69 & 16 & 40 & 84 & 175 \\
\hline
\end{tabular}

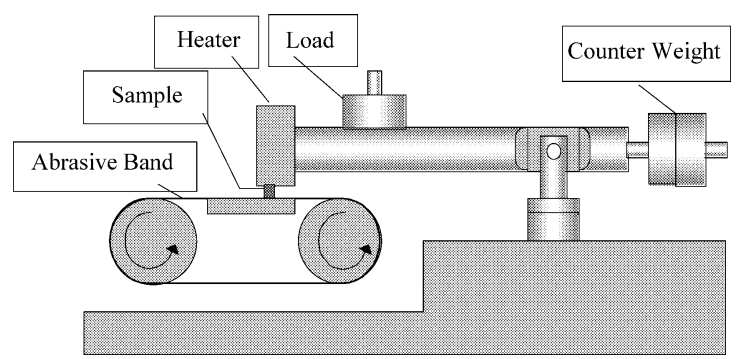

Fig. 2. Schematic view of the abrasive wear tester utilised in this study.

\section{Results and Discussion}

Tensile test results of the investigated ductile irons are presented in Fig. 3 as "Stress-Strain" curves. Serrated flow, which is the common feature of dynamic strain aging, is apparent in the temperature range between $100-300^{\circ} \mathrm{C}$ and much more pronounced for the material DI 1 than the mate-

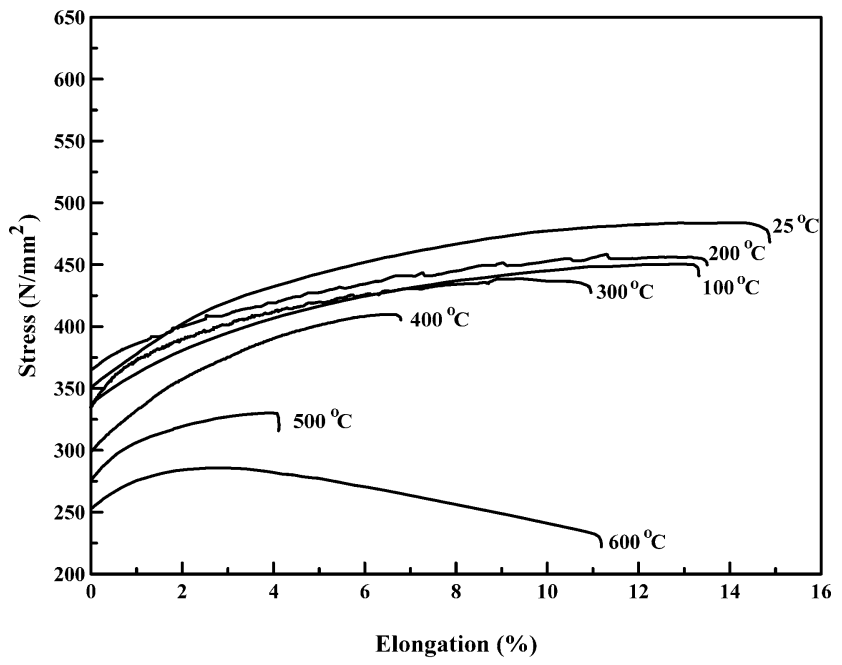

(a)

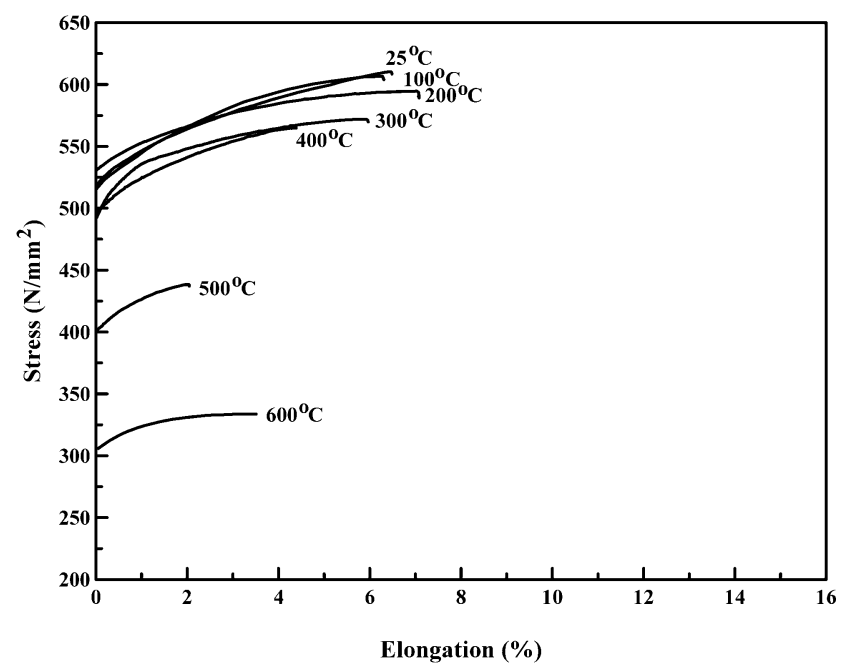

(b)

Fig. 3. Stress-Strain curves of (a) the material DI 1 and (b) the material DI 2.

rial DI 2.

Previously, Lui and $\mathrm{Chao}^{9)}$ reported serrated flow during low strain rate $\left(3 \times 10^{-4} / \mathrm{s}\right)$ tensile testing of a ferritic ductile iron in the temperature interval between 150 and $350^{\circ} \mathrm{C}$. Shieh et al. ${ }^{10)}$ presented serrated flow on the "StressStrain" curves of bainitic austempered ductile irons at testing temperatures lower than $280^{\circ} \mathrm{C}$, which was attributed to the presence of acicular ferrite in the microstructure. Since higher volume fraction of ferrite contribute to the distinct dynamic strain aging, serrated flow is more apparent on the "Stress-Strain" curves of the material DI 1 than that of the material DI 2.

Dynamic strain aging, which leads to inhomogeneous deformation characterised by serrated flow, is mainly relevant to the diffusion of interstitial atoms such as carbon or nitrogen to dislocations in motion. When the temperature and the strain rate are such that, the speed of interstitial atoms is more than that of dislocations, dislocations are pinned by interstitial atoms. Serrations occur due to rapid dislocation multiplication during deformation. In the process of dislocation multiplication stress increases, but once the dislocations are released the stress drops to sustain their movement 
until interstitial atoms diffuse and pin these mobile dislocations again. ${ }^{11-13)}$

The effect of test temperature on the strength and ductility of the investigated ductile irons is plotted in Figs. 4 and 5, respectively. The material DI 2 exhibited higher tensile strength and lower elongation at fracture values than the material DI 1 at the entire temperature range. The tensile strengths of both ductile irons were maintained almost constant up to $400^{\circ} \mathrm{C}$ and then dropped sharply at higher temperatures. It is reported that, ${ }^{10)}$ in the temperature ranges where dynamic strain aging occurs, the strength remains constant or increases slightly with increasing temperature due to strengthening effect of strain aging. Above $400^{\circ} \mathrm{C}$, decrease of the tensile strength is accompanied by severe

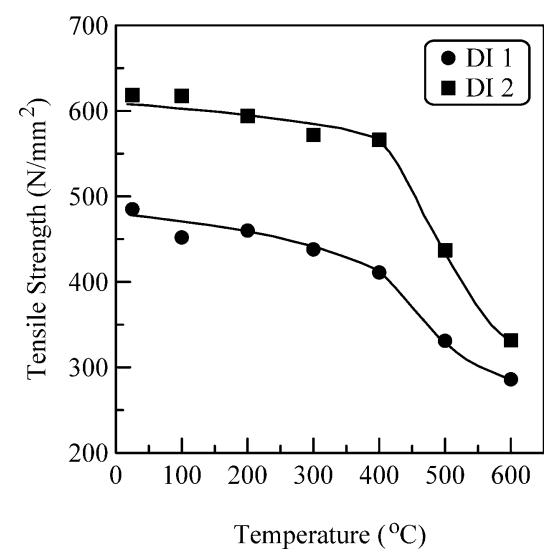

Fig. 4. The effect of test temperature on the tensile strengths of the investigated ductile irons.

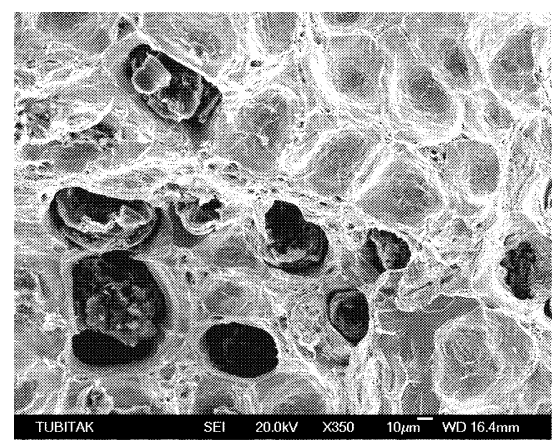

(a)
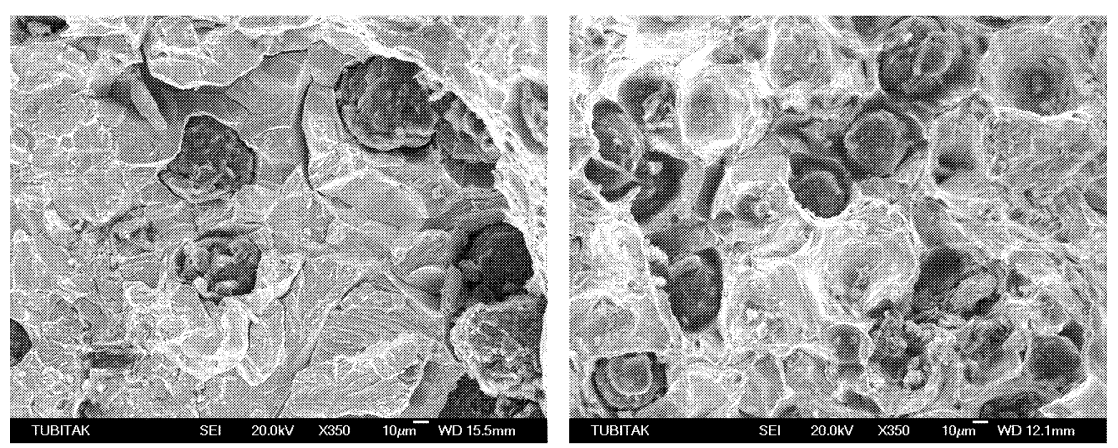

(c) decrease of elongation for both ductile irons. However, the material DI 1 exhibited minimum ductility at $500^{\circ} \mathrm{C}$, followed by an increase with further increase of test temperature to $600^{\circ} \mathrm{C}$. Lui and $\mathrm{Chao}^{9)}$ reported embrittlement temperature for a ferritic ductile iron as $400^{\circ} \mathrm{C}$ and attributed this embrittlement to dynamic strain aging such as blue brittleness of steel, in which solute atoms interact with dislocations.

Figures 6 and 7 show SEM micrographs of the fracture surfaces of the material DI 1 and the material DI 2 after tensile tests, respectively. On the fracture surfaces of the material DI 1 dimple pattern, which is the characteristic of ductile fracture, is dominant up to $500^{\circ} \mathrm{C}$ (Figs. 6(a) and $6(\mathrm{~b})$ ). At $500^{\circ} \mathrm{C}$, where minimum ductility is obtained (Fig.

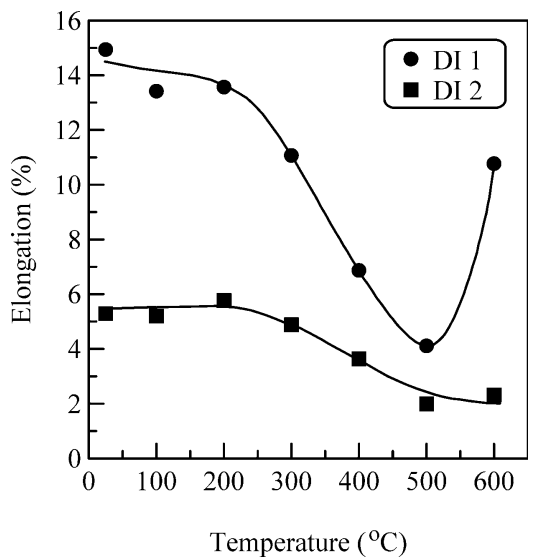

Fig. 5. The effect of test temperature on the elongation at fracture values of the investigated ductile irons.

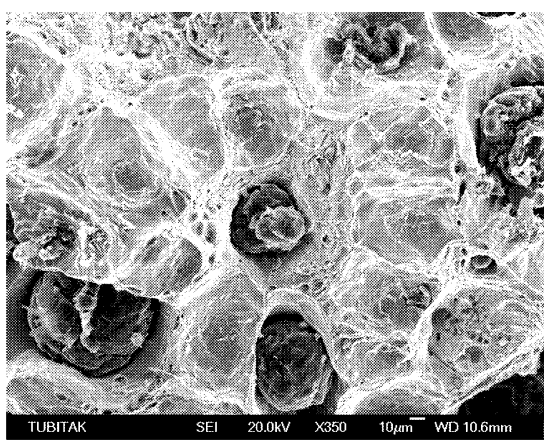

(b)

(d)

Fig. 6. Scanning electron micrographs of the fracture surfaces of the material DI 1 at (a) room temperature, (b) $200^{\circ} \mathrm{C}$, (c) $500^{\circ} \mathrm{C}$ and (d) $600^{\circ} \mathrm{C}$. 


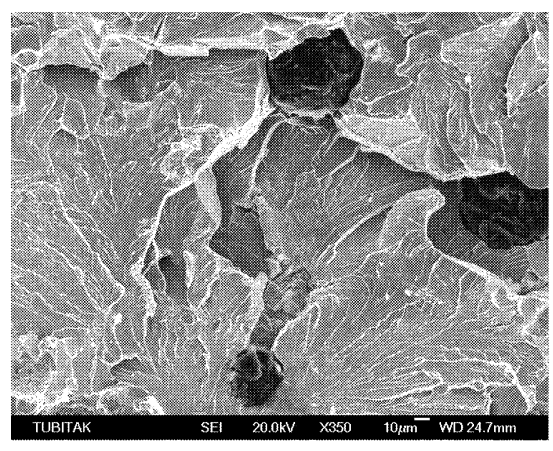

(a)

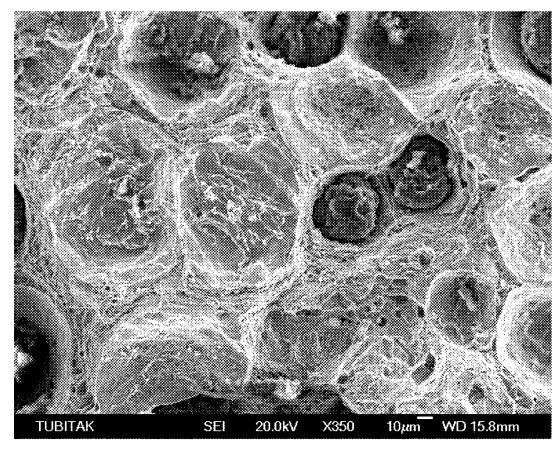

(c)

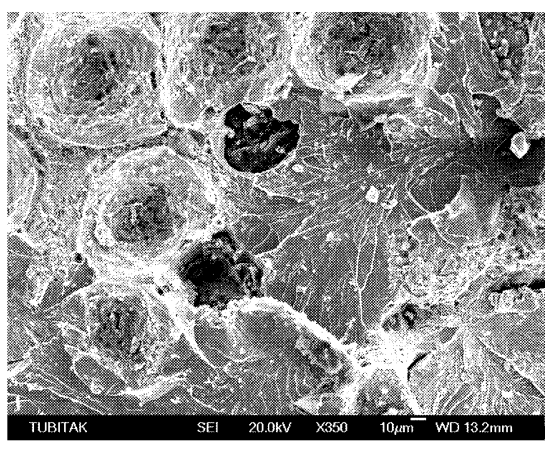

(b)

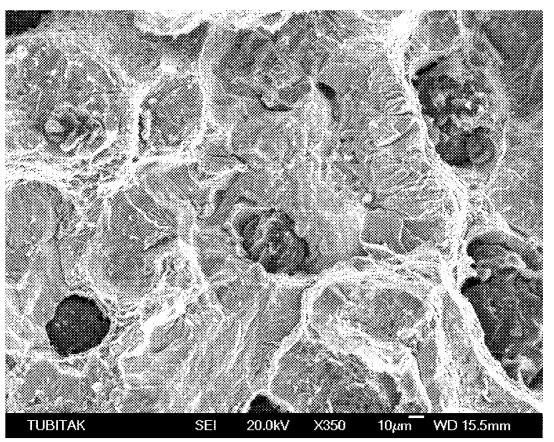

(d)

Fig. 7. Scanning electron micrographs of the fracture surfaces of the material DI 2 at (a) room temperature, (b) $200^{\circ} \mathrm{C}$, (c) $500^{\circ} \mathrm{C}$ and (d) $600^{\circ} \mathrm{C}$

5), the fracture surface changed from dimple pattern to mixed fracture pattern (Fig. 6(c)), which includes a certain amount of cleavage fracture pattern. At $600^{\circ} \mathrm{C}$, dimple pattern appeared again on the fracture surface (Fig. 6(d)) with increasing ductility (Fig. 5). Thus, $500^{\circ} \mathrm{C}$ corresponds to embrittlement temperature for the material DI 1 . The fracture surfaces of the material DI 2 tested at room temperature and $600^{\circ} \mathrm{C}$ exhibited mainly cleavage fracture pattern as seen in Figs. 7(a) and 7(d), respectively. On the fracture surfaces of the material DI 2 tested at medium temperatures mixed cleavage fracture and dimple patterns were observed (Figs. 7(b) and 7(c)). Shieh et al. ${ }^{10)}$ observed cleavage fracture pattern on the fracture surfaces of bainitic ductile irons above $300^{\circ} \mathrm{C}$, where elongation decreases dramatically with increasing temperature.

The results of abrasive wear tests carried out at different temperatures are presented in Fig. 8 as "Weight LossTemperature" graph. At the entire temperature range, the weight loss of the material DI 1 is higher than that of the material DI 2. Higher abrasion resistance of the material DI 2 can be attributed to presence of higher volume fraction of pearlite in the microstructure. As a general trend, weight loss of both ductile irons increased and abrasion resistance decreased with increasing test temperature. However, both ductile irons exhibited minimum weight loss at $100^{\circ} \mathrm{C}$, which corresponds to the beginning temperature of serrated flow during tensile testing due to dynamic strain aging (Fig. 3 ). In this temperature regime both ductile irons exhibited about $15 \%$ higher abrasion resistance than room temperature.

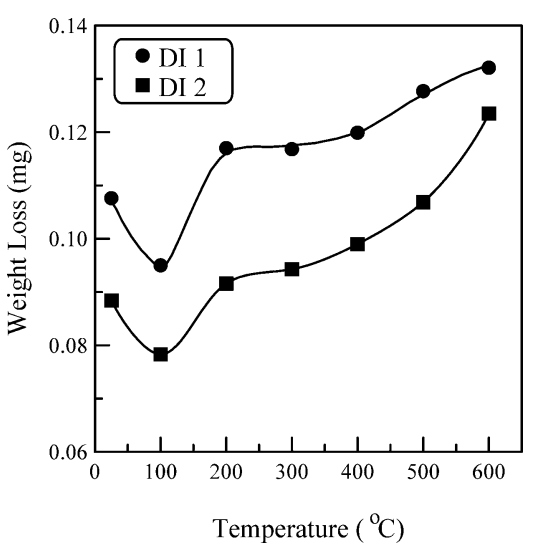

Fig. 8. The effect of test temperature on the weight loss of the investigated ductile irons

SEM micrographs of the worn surfaces are presented in Figs. 9 and $\mathbf{1 0}$ for the material DI 1 and the material DI 2, respectively. Worn surfaces of both ductile irons can be characterised by typical abrasive grooves and embedded abrasive grains. Plastic deformation has taken place at edges of the grooves. Worn surface topographies indicate the dominant wear mechanism as ploughing. It is evident from Figs. 9 and 10 that, the worn surface damage is heavy for the material DI 1 than that of the material DI 2 at entire temperature range in accordance with their mechanical properties.

Since hardness and strength play the major role in wear resistance of metallic materials, the correlation between 


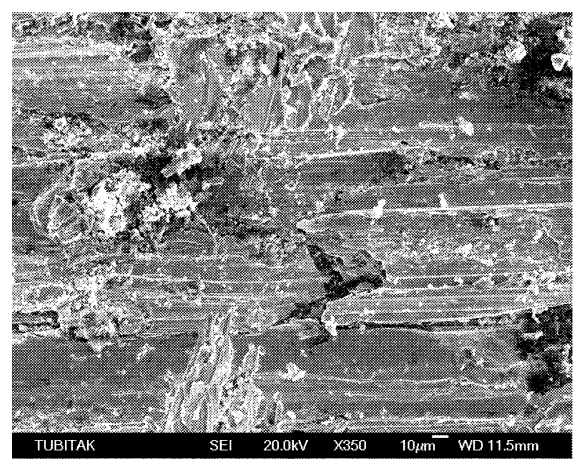

(a)

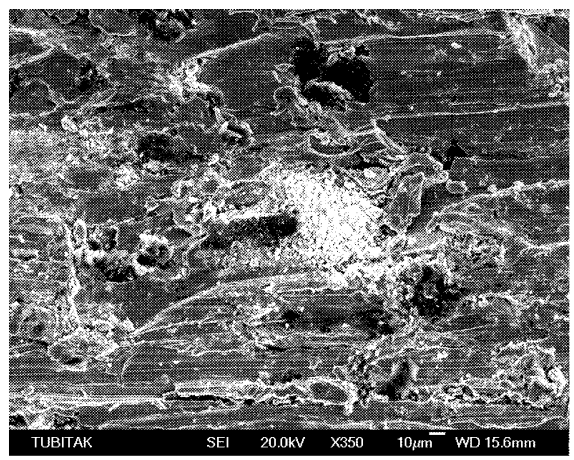

(b)

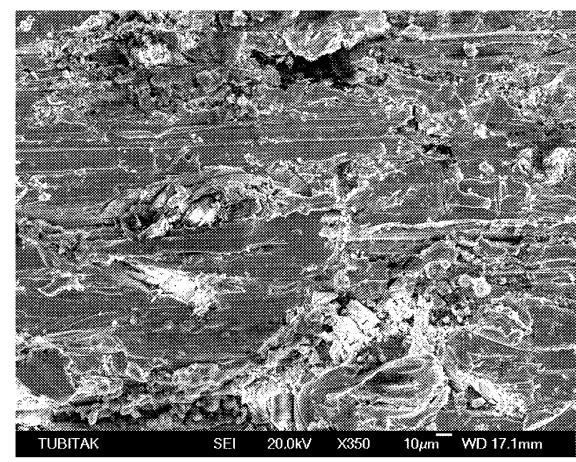

(c)

Fig. 9. Scanning electron micrographs of the worn surfaces of the material DI 1 at (a) room temperature, (b) $100^{\circ} \mathrm{C}$ and (c) $600^{\circ} \mathrm{C}$.

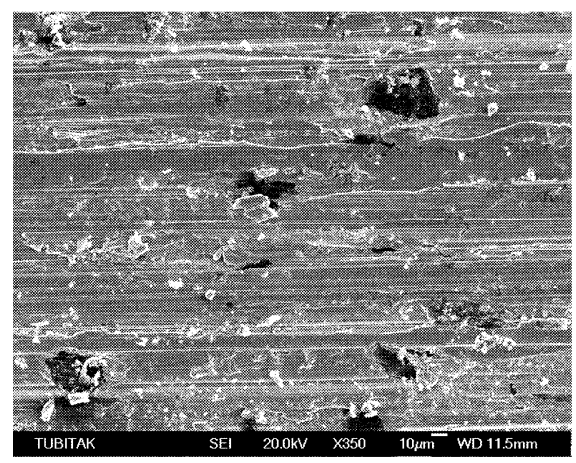

(a)

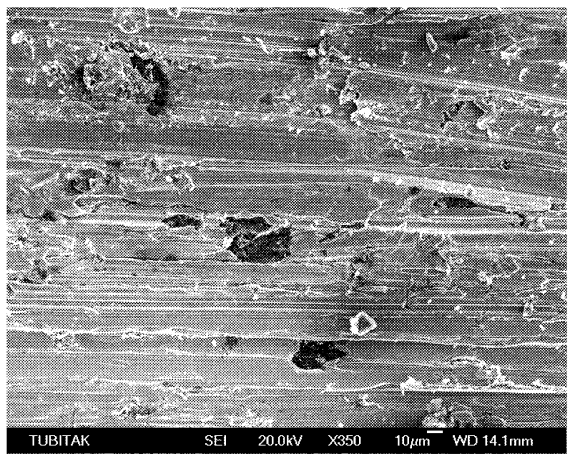

(b)

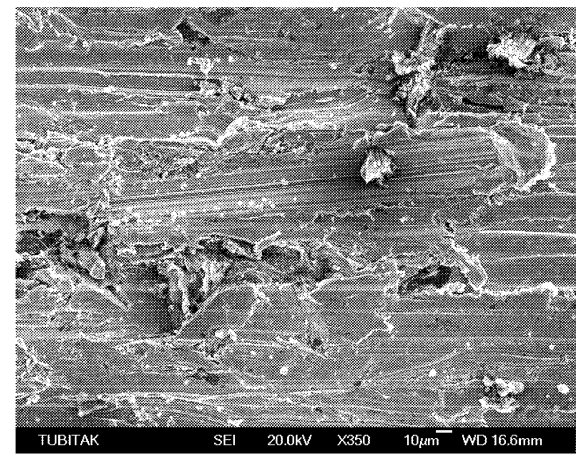

(c)

Fig. 10. Scanning electron micrographs of the worn surfaces of the material DI 2 at (a) room temperature, (b) $100^{\circ} \mathrm{C}$ and (c) $600^{\circ} \mathrm{C}$.

weight loss and tensile strength are plotted in Fig. 11. As a general trend, weight loss decreased and wear resistance increased with increasing tensile strength. It should be mentioned that, at high tensile strength values of each ductile iron, weight loss data are sharply shifted to lower values, which can be attributed to low temperature $\left(100^{\circ} \mathrm{C}\right)$ dynamic strain aging.

\section{Conclusions}

Based on the results of tensile and abrasive wear tests conducted on ferritic ( $84 \%$ ferrite $+5 \%$ pearlite and $11 \%$ graphite) and pearlitic ( $15 \%$ ferrite $+69 \%$ pearlite and $16 \%$ graphite) matrix ductile irons at temperature interval between room temperature and $600^{\circ} \mathrm{C}$, the following conclusions can be drawn;

(1) At entire temperature range pearlitic ductile iron exhibited higher strength and lower ductility than ferritic ductile iron. High temperature tensile testing caused serrated flow in the temperature range between 100 and $300^{\circ} \mathrm{C}$. In this temperature regime, tensile strength values of both ductile irons were almost invariable. Above $400^{\circ} \mathrm{C}$, increase of temperature decreased both tensile strength and ductility dramatically. However, ferritic ductile iron exhibited significantly higher ductility at 600 than $500^{\circ} \mathrm{C}$.

(2) High strength pearlitic ductile iron exhibited higher abrasion resistance than low strength ferritic ductile iron in

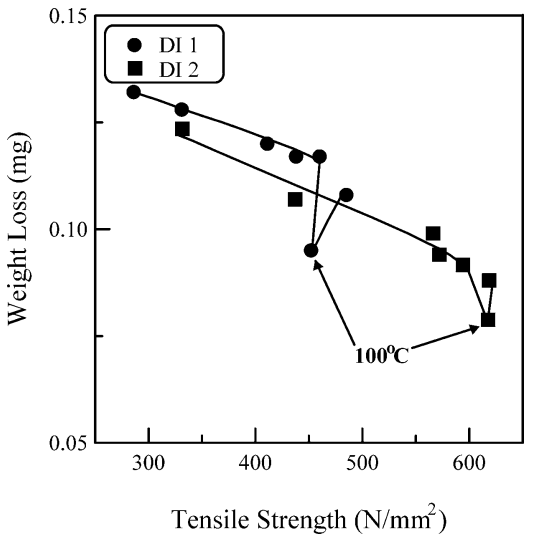

Fig. 11. The correlation between weight loss and tensile strength for the investigated ductile irons.

entire temperature range. As a general trend, abrasion resistance increased with increasing tensile strength. Dynamic strain aging caused further improvement of abrasion resistance. The highest resistance to abrasive wear is observed at $100^{\circ} \mathrm{C}$. At this temperature both ductile irons exhibited about $15 \%$ higher abrasion resistance than room temperature.

\section{Acknowledgments}

The authors would like to thank Mr. E. F. Özdoğru for kindly carrying out SEM studies. The assistance of Mr. M. 
Canıbeyaz for high temperature tensile tests is also appreciated.

\section{REFERENCES}

1) M. C. Jeng: J. Mater. Sci., 28 (1993), 6555.

2) Q. Luo, J. Xie and Y. Song: Wear, 184 (1995), 1.

3) M. Baydogan, M. U. Kokden and H. Çimenoğlu: Steels and Materials for Power Plants, EUROMAT '99, Vol. 7, ed. by P. Neumann, D. Allen and E. Tenckhoff, Wiley-VCH, Munich, (1999), 219

4) A. S. M. A. Haseeb, M. A. Islam and M. M. A. Bepari: Wear, 244 (2000), 15

5) M. Baydogan and H. Çimenoğlu: Scand. J. Metall., 30 (2001), 391.
6) Z. L. Lu, Y. X. Zhou, Q. C. Rao and Z. H. Jin: J. Mater. Process. Technol., 116 (2001), 176.

7) N. Rebasa, R. Dommarco and J. Sikora: Wear, 253 (2002), 855

8) O. Celik: M. Sc. Thesis, I.T.U. Institute of Science and Technology, Istanbul, (2001) (in Turkish)

9) T. S. Lui and C. G. Chao: J. Mater. Sci., 24 (1989), 2503.

10) C. S. Shieh, T. S. Lui and L. H. Chen: Mater. Trans. JIM, 36 (1995), 620 .

11) R. E. R. Hill: Physical Metallurgy Prenciples, D. Van Nostrand Company, New York, (1973), 347.

12) A. K. Sachdev: Metall. Trans. A, 13A (1982), 1793.

13) Verein Deutscher Eisenhüttenleute: Steel: A Handbook for Materials Research and Engineering, Vol. 1: Fundamentals, v1, SpringerVerlag, Düsseldorf, (1993), 218. 